\title{
People Perception on Climate Change and Their Influence on Various Aspects Around Tones Valley of Garhwal Himalaya
}

\author{
Vardan Singh Rawat \\ Department of Botany, D.S.B. Campus, Kumaun University, Nainital, Uttarakhand \\ Corresponding Author: singhvardan@rediffmail.com
}

Copyright (C) 2013 Horizon Research Publishing All rights reserved.

\begin{abstract}
Climate change is already being experienced by the community in the form of irregular rainfall and snow fall, increasing temperature, decreasing moisture content as a result some plant species have changed their new leaf formation time, flowering and fruiting time, which is now 15 to 20 days ahead as compared to the timings 10-15 years ago. Furthermore, changes in flowering and fruiting time, increased invade species like Parthinium hysteroporus, Agerative spp, Lantana camera in the farm land as well as forest land. Low amount of snow fall in the Himalayan region affected to the Nomad groups due low grass available to feed their livestock. Climate and weather also determine food security of the hill communities, who rely on agriculture and animal husbandry for their subsistence needs. These persistent changes in the weather have resulted in the overall decrease in the quantity of available water in all the water sources of the region. The present study revealed that a majority of farmers $(56 \%)$ were aware about global warming and hence about the changes in the climate $(52 \%)$. A significant percentage of them $(86 \%)$ were agreed that persistent change in the climate has dried the water bodies, adversely affected the quantity and quality of various fruits. Broad leave species are being replaced with pine which is a major cause of forest fires. Crop productivity has been reduced because of low soil fertility and higher incidence of diseases. A positive change observed by villagers is that the ripening period of wheat has reduced by some days. Adapting to climate change, people have started cultivation of crop varieties that required less water. Villagers have also adopted new enterprises for income generation. Forest, soil and water conservation are some important issues highlighted by community to reduce future risks. Such knowledge can allow scientists to test specific hypotheses, and policy makers to design mitigation and adaptation strategies for climate change, especially in an extraordinarily important part of our world that is experiencing considerable change.
\end{abstract}

Keywords Community Forest, Tones valley, Himalaya, Nomad

\section{Introduction}

Climate change is now recognized as a phenomenon that will be seen and experienced by people all over the world. It poses new challenges to natural resource management and livelihood. There is a broad scientific consensus that some impacts of climate change are already observable and further changes will occur. Due to the impact of global warming, the atmospheric temperature is increasing in a dramatic manner. There are a number of ways in which forests could be affected by change in climatic factors. Enhanced temperatures boost up transpiration rates, ecological processes such as succession and migration could also be influenced by changes in temperature and moisture regimes. However, Himalayan region might see more changes. The Himalayan region are geo-ecologically important for the adjacent Gangetic Plain where nearly 500 million people live. People have been doing agriculture in this region for several thousand years, and the region is famous for the green revolution that helped India solve its food crisis. The global warming might severely affect the rivers that flow from the Himalayas through the Gangetic Plains, as well as the climate regime of the entire region. Himalayan degradation coupled with global warming is imposing severe threats to the existing environmental problems. Recent modeling studies suggest that the forest ecosystems can be seriously impacted by future climate change, even with a rise in 1 to 2 ${ }^{\circ} \mathrm{C}$, will be impacted through changes in species composition, productivity and biodiversity. These will also have an impact on the people who depend upon the forests for their livelihoods. The livelihoods of Himalayan people are directly dependent on forests and agricultural systems. Any change in the structure, composition and distribution of forests is expected to have severe consequences for communities and their economies, which depend on these forests. It would be advantageous for the communities, in the long term, to identify trends with the available knowledge 
and develop ways of adapting to future impacts of climate change. In addition to the already existing threats and pressures on mountain ecosystem, climate change can be an additional burden to bear by the mountain ecosystems, species and peoples.

In order to understand how human beings would respond to climate change, it is essential to study people perceptions of climate and the environment in general (Vedwan et al. 2001). Human expectations regarding weather and climate sometimes lead to perceptions of climate change which are not supported by observational evidences (Rebetcz, 2000). Studies focussing on the socioeconomic aspects of climatic change are sparse and have almost exclusively restricted their analysis to the impact of environmental modifications on agricultural production (Scott et.al., 1990). Thus, the present study is a small step towards understanding of climate change impacts and the patterns of human responses for future studies.

\subsection{Description of Study Site}

The present study was conducted in the tribal localities of Tones Valley residing in Govind Wild Life Sanctuary and National Park of Uttarkashi district of Uttarakhand (Fig 1), located at $30^{\circ} 35^{\prime}$ and $30^{\circ} 18^{\prime} \mathrm{N}$ latitude and $77^{\circ} 49^{\prime}$ and $78^{\circ}$ $37^{\prime} \mathrm{E}$ longitude in the temperate part of the West Central Himalaya at an altitudinal range of 1000-3200 $\mathrm{m}$. The valley is bounded in the north and north-east by Shimla district of Himachal Pradesh and in south-west by Dehradun district of Uttarakhand. The total area of the valley is $4500 \mathrm{~km}^{2}$. Rupin and Supin are the main tributaries of Tones River.

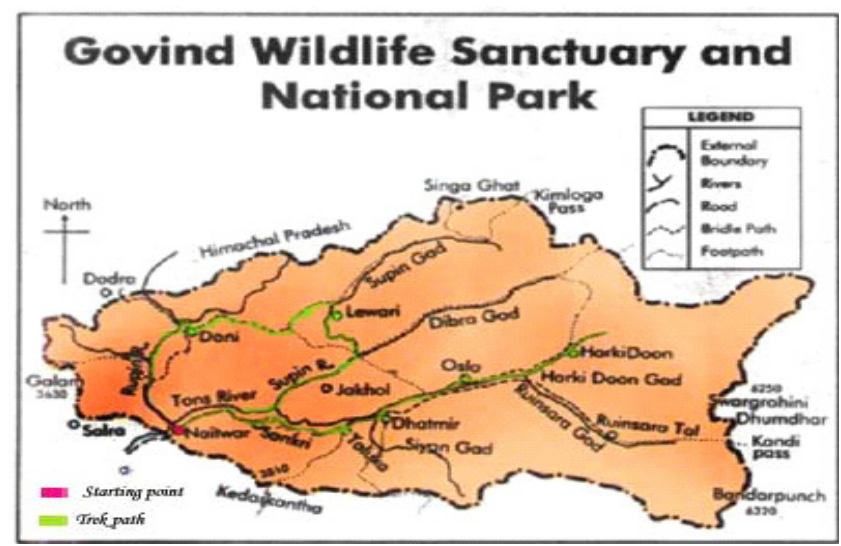

Figure 1. Study map of Govind Wild life Sanctuary and National Park

\subsection{Climate}

The climate of the study area is influenced by the monsoon rhythm of rainfall. There are three main seasons, the winter (December to March), summer (April to June) and rainy season (July to September). The transition period between summer and winter and winter and summer can be recognized as autumn (October to November) and spring (February to March), respectively. The climate of the lower part of study site have subtropical with more or less humid monsoon season from July to September, at higher elevation it is cool even in June, winter is long with heavy snowfall from December to March. Winter experiences severe cold the main precipitations are received in the form of snow. Maximum snow depth occurs in the sub-alpine and alpine areas during December- February.

\subsection{Soil}

Geologically the area forms the krol belt with metamorphic and sedimentary rock type. The soil is differentiated into red loam, brown forest podosol and meadow type (Rawat, et. al., 2010).

\section{Materials and Method}

The valley is a homeland of the several tribes dominated by Pravatis and Banganis (Similar to Jaunsari tribe of Dehradun). However in January, 2004 they are included in Other Backward Class (O.B.C.) under Raunwalta community. Majority of the people are dependent on agriculture and animal husbandry. There are a considerable number of people employed in government and non government enterprises. Very few people are associated with the traditional skill based work such as masonry, tailoring, carpentry or other work. Livestock and animal husbandry have made these people more dependent on their immediate environment, and accordingly they have diversified their resource use practices. Due to their seasonal movements between their summer settlements (JuneSeptember) in higher altitude $(3000-4000 \mathrm{~m})$ and winter settlement (up to $1500 \mathrm{~m}$ ) they are well informed and in touch with different floristic composition and a wide range of natural resources. The fragility of high altitude is best exemplified by these people.

The information was gathered from 100 household administered in 20 villages after long session interview and focus group discussions carried out with separate groups of women and men viz: climate change, reason of climate change, phenological changes in different plants (flowering and fruiting), changing in rain fall and snow fall pattern and suggestion on mitigation of climate change. The perception of the respondents on the effects of climate change was measured with the help of the scale developed for the purpose. The socioeconomic information was gathered from three different age groups viz., 30-35 year, 51-70 and above 70 year. Socio economic status was also considered from the villagers due to climate change impact. The scale consisted of 31 statements/items (Edwards and Kilpatrick (1948). The response of each respondent against each statement was obtained, on a five point continuum scale viz. Strongly Agree, Agree, don't know, Disagree and Strongly Disagree with respective score of 5, 4, 3, 2, and 1 for positive statement and the scoring was reversed in case of negative statement. 


\section{Results}

According to people's perception, climate change affects the phenological events like flowering, fruiting. The maximum effect of climate change according to people can be seen on Quercus lecutrichophora, Rhododendron arboreum, Rubus ellipticus, Pyrus communis, Prinsepia utilis Bergenia strachii, Aconitum heterophyllum etc. Phenological changes occur due to irregular rainfall and snow fall, increasing temperature, decreasing moisture content as a result all plants have changed their new leaf formation time, flowering and fruiting time, which is now 15 to 20 days ahead as compared to the timings 10-15 years ago. In the present study majority of the respondents were illiterate $(77 \%)$ with joint family $(40 \%)$ system. increasing western culture turned joined families to nuclear family (60\%) (Table 1) $56 \%$ of the respondents were aware about the global warming and knew that there was a change in the climate. More than $80 \%$ respondent pointed out that due to change in climate there is unpredictable snowfall, climate is getting warmer day by day due to rise in temperature, flood incidence was increasing due to melting of glaciers (Table 2). In the present study majority of the respondents either strongly agreed or agreed that due to climate change, ground water level and food grain production has decreased. Climate change has increased the frequency of rainfall, Soil erosion and risk of crop failure. Natural regeneration of broad leaf species like oak has been adversely affected besides flowering and fruiting time also changed in some spp. It is also perceived by a substantial percentage of respondents that water sources have dried up $(100 \%)$, and it has discouraged farmers to grow traditional crops like olga, phagra, mandua etc. ( $85 \%)$, drudgery of farm women has increased $(65 \%)$, climate change has caused scarcity of fodder in the area (79\%). However, $96 \%$ of the respondents disagreed and strongly disagreed that climate change has improved the health status of the local people (Table 3). Crop and seed dispersal has also been effected by decrease in insect's population and affecting production of cash crops like potato, rye, til, Cholai and rajama in the present studied area. A majority of respondents had perceived that the area under fruit crops and cereal crops had increased $(76 \%$ and $45 \%$, respectively). Uses of fertilizers and pesticides have also increased due to climate change (94\% and $85 \%$, respectively; Table 4).

Table 1. Demographic profile of the studied villagers

\begin{tabular}{|c|c|c|}
\hline Sl. No. & Socioeconomic characteristics & Frequency $(\%)$ \\
\hline \multicolumn{3}{|c|}{ Age group } \\
\hline I & $30-50$ & 35 \\
\hline II & $51-70$ & 35 \\
\hline III & Above 70 & 30 \\
\hline \multicolumn{3}{|c|}{ Education qualification } \\
\hline I & Primary & 10 \\
\hline II & Secondary & 6 \\
\hline III & Senior Secondary & 2 \\
\hline IV & Graduate & 4 \\
\hline $\mathrm{V}$ & Post graduate & 1 \\
\hline VI & Illiterate & 77 \\
\hline \multicolumn{3}{|c|}{ Family type } \\
\hline \multirow[t]{2}{*}{ I } & Nuclear & 60 \\
\hline & Joint & 40 \\
\hline
\end{tabular}


Table 2. Awareness and Knowledge on the types of climate change

\begin{tabular}{|c|c|c|}
\hline \multicolumn{2}{|c|}{ Awareness about global warming } & Frequency (\%) \\
\hline Sl. No. & Awareness & 56 \\
\hline I & Yes & Frequency (\%) \\
\hline II & No & 92 \\
\hline \multicolumn{2}{|c|}{ Knowledge on the types of climate change } \\
\hline I & Perceived Knowledge & 86 \\
\hline II & Increasing pollution & 94 \\
\hline III & Increase in temperature & 55 \\
\hline IV & Climate is getting warmer & 73 \\
\hline V & Causes of forest fire increased & 79 \\
\hline VI & Occurrence of extreme weather conditions & 74 \\
\hline VII & Frequency of drought have increased & 100 \\
\hline VIII & Monsoon has become unpredictable & 83 \\
\hline IX & Increase in the incidence of flood & 85 \\
\hline X & Rise in the risk of crop failure has increased & 88 \\
\hline XI & Snowfall has become unpredictable & \\
\hline
\end{tabular}

Table 3. Perception and knowledge on the effects of climate change

\begin{tabular}{|c|c|c|c|c|c|c|}
\hline & & \multicolumn{5}{|c|}{ Responses } \\
\hline $\begin{array}{l}\text { Sl. } \\
\text { NO }\end{array}$ & Statement & SA $(\%)$ & $\mathrm{A}(\%)$ & UD (\%) & $\begin{array}{l}\text { DA } \\
(\%)\end{array}$ & SDA $(\%)$ \\
\hline 1 & $\begin{array}{l}\text { Due to climate change food grain production has } \\
\text { decreased }\end{array}$ & 60 & 40 & - & - & - \\
\hline 2 & Climate change has no effect on snow fall & - & - & 2 & 14 & 84 \\
\hline 3 & $\begin{array}{l}\text { Water sources have dried up due to change in } \\
\text { climate }\end{array}$ & 66 & 34 & - & - & - \\
\hline 4 & Climate change has increased the risk of crop failure & 64 & 32 & 4 & - & - \\
\hline 5 & $\begin{array}{c}\text { Change in climate has increased the frequency of } \\
\text { rainfall }\end{array}$ & 33 & 57 & 6 & 4 & \\
\hline 6 & $\begin{array}{c}\text { Climate change has no effect on the incidences of } \\
\text { insect pest and diseases }\end{array}$ & - & 2 & 3 & 43 & 52 \\
\hline 7 & $\begin{array}{l}\text { Because of climate change, the incidences of } \\
\text { untimely rainfall have increased }\end{array}$ & 24 & 58 & 2 & 12 & 4 \\
\hline 8 & $\begin{array}{l}\text { Due to climate change, level of ground water has } \\
\text { decreased }\end{array}$ & 56 & 43 & 1 & - & - \\
\hline 9 & Soil erosion has increased due to climate change & 44 & 53 & 3 & - & - \\
\hline 10 & Climate Change has resulted due to deforestation & 57 & 41 & 2 & - & - \\
\hline 11 & $\begin{array}{l}\text { Climate change has caused scarcity of fodder in the } \\
\text { area }\end{array}$ & 23 & 56 & 12 & 6 & 3 \\
\hline 12 & $\begin{array}{l}\text { Due to climate change drudgery of farm women has } \\
\text { increased }\end{array}$ & 21 & 44 & 22 & 10 & 3 \\
\hline 13 & $\begin{array}{l}\text { Natural regeneration of Oak spp. has been adversely } \\
\text { affected due to climate change }\end{array}$ & 21 & 38 & 28 & 11 & 2 \\
\hline 14 & $\begin{array}{l}\text { climate change has discouraged the farmer to grow } \\
\text { crops like olga, phagra, mandua etc }\end{array}$ & 41 & 44 & 5 & 6 & 4 \\
\hline 15 & $\begin{array}{l}\text { Climate change has improved the health status of the } \\
\text { local people }\end{array}$ & - & - & 4 & 45 & 51 \\
\hline 16 & $\begin{array}{l}\text { Climate change has facilitated the availability of } \\
\text { fresh vegetables/ fruits etc. in the area }\end{array}$ & 12 & 59 & 14 & 11 & 3 \\
\hline 17 & Fruit size decreased due climate change & 32 & 56 & 9 & 3 & - \\
\hline 18 & $\begin{array}{l}\text { Flowering and fruiting time changed in some spp. } \\
\text { due to change in climate }\end{array}$ & 42 & 48 & 7 & 3 & - \\
\hline
\end{tabular}


Table 4. Effect of climate change on agricultural and related aspects

\begin{tabular}{|c|c|c|c|c|c|}
\hline \multirow{2}{*}{ Sl. No } & \multirow{2}{*}{ Aspect } & \multicolumn{4}{|c|}{ Perceived responses } \\
\cline { 3 - 6 } & & increased & decreased & same & Can't say \\
\hline 1 & Area under cereal crop cultivation & 45 & 15 & 24 & 16 \\
\hline 2 & Area under fruit crops & 76 & 10 & 6 & 8 \\
\hline 3 & Area under forest & 28 & 65 & 4 & 3 \\
\hline 4 & Use of fertilizers in the crops & 94 & - & 06 & - \\
\hline 5 & Use of pesticides in different crops & 85 & - & 06 & 09 \\
\hline
\end{tabular}

\section{Discussion}

Tons valley is experiencing a lot of changing due to effect of climate change. Phenological changes occur due to irregular rainfall and snow fall, increasing temperature, decreasing moisture content as a result all plants have changed their new leaf formation time, flowering and fruiting time, which is now 15 to 20 days ahead as vii. compared to the timings $10-15$ years ago. The maximum effect of climate change can be seen on Quercus viii. lecutrichophora, Rhododendron arboreum, Rubus ellipticus, Pyrus communis, Prinsepia utilis Bergenia strachii, ix. Aconitum heterophyllum etc.

The present study revealed that a majority of farmers $(56 \%)$ were aware about global warming and hence about the changes in the climate $(52 \%)$. A significant percentage of them $(86 \%)$ were agreed that persistent change in the climate has dried the water bodies, adversely affected the quantity and quality of various fruits. Decreased production of traditional crops like olga, china, chaulai, phafra, mandua etc. The climate change has resulted in irregularity in rainfall and snowfall, decreased ground water, incidences of attacks of insect and pest increases. Inadequate chilling hours, problems in pollination, inclination towards cash crops and preference for early maturing varieties demanding less water etc. were the main reasons for change in cropping pattern due to climate change. According to people perception there are many reasons of climate change viz lack of awareness about role of forest in climate change mitigation, increasing human population increases pressure on forest and forest fire. Use of non degradable matter and number of vehicles has increased beside fertilizers, pesticides and insecticides.

Suggestions for the mitigation of climate changes-

i. Concerted efforts are required to save and protect the forests.

ii. Forest right should be given to the Panchayati Raj institutes .

iii. The responsibility of the village based institution like Van Panchayat, Mahila Mangal Dal, Youvak Mangal Dal, Self Help Groups should be made clear by the Government and forest department for their protection and management.

iv. Social and public awareness campaigns should be carried out to educate people .

v. Compulsory subject of climate change should be started on schools and collage level.

The Government should ban the uses of non biodegradable products.

Prevention and control of forest fire through community participation and awareness.

Clear forest protection and management policy should be implemented on the ground

Reduction in the number of motor vehicles and factories.

The department of forest or irrigation should undertake rain water conservation measures by constructing Chals and Khals.

xi. More and more plantation should be done around the water sources.

\section{REFERENCES}

[1] Edwards, A. L. and Kilpatrick (1948). Informal criteria for attitude statements. In: Techniques of attitude scale construction (Edwards, Allen L.) New York, Appletoncentury crofts, Inc.

[2] Rebetcz, M. (2000). Public expectations as an element of human perceptions of climate change, climatic change, Springer, Netherlands, 32: 495-509.

[3] Rawat, V.S., Rawat, Y.S. and Shah, S. (2010). Indigenous knowledge and sustainable development in the Tones Valley of Garhwal Himalaya Journal of Medicinal Plant Research 4(19): 2043-2047.

[4] Scott, M.S., Rosenberg, N.J, Edmonds, J.A., Cushman, R.M. and 7 others (1990). Consequences of climate change for human environment, Clim Res. 1:63-79.

[5] Vedwan, N., Rhoades, R.E. (2001). Climate change in the western Himalayas of India : A study of local perceptions and response, Clim. Res. 19:109-117. 